\title{
Faktor-Faktor yang berhubungan dengan Kesiapsiagaan Bidan dalam Menghadapi Bencana Gempa dan Tsunami di Puskesmas Kota Padang
}

\author{
Novria Hesti ${ }^{1}$, Husna Yetti ${ }^{2}$, Erwani $^{3}$
}

\begin{abstract}
Abstrak
Ada lebih dari sepertiga kasus kematian ibu terjadi ditengah bencana, salah satu penyebabnya adalah kurangnya peralatan dan personel yang berkualifikasi dalam sistim perawatan kesehatan. Tujuan penelitian ini adalah menentukan faktor-faktor yang berhubungan dengan kesiapsiagaan bidan dalam menghadapi bencana Gempa dan Tsunami di puskesmas kota Padang tahun 2018. Jenis penelitian adalah analitik dengan desain cross sectional yang dilakukan di puskesmas; Lubuk Buaya, Ulak Karang, Air Tawar, Padang Pasir, Seberang Padang dan Pemancungan pada bulan Oktober sampai November 2018 terhadap 48 orang bidan yang bekerja di puskesmas dengan menggunakan teknik proportional random sampling. Data dikumpulkan dengan wawancara menggunakan kuesioner. Analisis bivariat menggunakan uji Chi-square dan analisis multivariat menggunakan uji regresi logistik ganda. Hasil penelitian ini diperoleh bahwa kesiapsiagaan bidan adalah siap 47,9 \% dan kurang siap 52,1\%. Bidan memiliki sikap positif $58,3 \%$ dan negatif $41,7 \%$. Bidan tidak pernah mengikuti pelatihan $54,2 \%$ dan pernah pelatihan $45,8 \%$. Faktor yang berhubungan dengan kesiapsiagaan bidan dalam menghadapi bencana antara lain tingkat pengetahuan $(p=0,001)$, Sikap $(p=0,017)$, pelatihan $(p=0,04)$. Simpulan penelitian ini adalah terdapat hubungan tingkat pengetahuan, sikap dan pelatihan dengan kesiapsiagaan bencana. Faktor yang paling dominan terhadap kesiapsiagaan bencana adalah pelatihan.
\end{abstract}

Kata kunci: kesiapsiagaan, tingkat pengetahuan, sikap, pelatihan

\begin{abstract}
More than one third of cases of maternal death occur amid disasters, one of which is the lack of equipment and qualified personnel in the health care system. The objective of this study was to find out the factors related to midwife preparedness on earthquake and tsunami disasters in Padang city health centers in 2018. This type of research was analytic with cross sectional design. This research was conducted at primary health center/puskesmas; Lubuk Buaya, Ulak Karang, Air Tawar, Padang, Seberang Padang and Pemancungan in October until November 2018 to 48 midwives who worked in the puskesmas using proportional random sampling techniques. Data was collected by interview using a questionnaire. Bivariate analysis using Chi-square test and multivariate analysis using multiple logistic regression tests. The results of this study found that $47.9 \%$ preparedness of midwives was ready and $52,1 \%$ not ready. 58.35\%. Midwives had a positive attitude 58,3\% and negative attitude 41,7\%. There were 54.2\% had never attended training and ever attended training 45,8\%. Factors related to midwives' preparedness in dealing with disasters include knowledge level ( $p=0.001)$, attitude $(p=0.017)$, training $(0.04)$. The conclusion of this study is that there is a relationship between the level of knowledge, attitudes and training with disaster preparedness. the most dominant factor with disaster preparedness is training.
\end{abstract}

Keywords: preparedness, knowledge level, attitude, training

Affiliasi penulis:1. Prodi S2 Kebidanan Fakultas Kedokteran Universitas Andalas Padang (FK Unand) 2. Bagian IImu Kesehatan Masyarakat FK Unand, 3. Bagian Jurusan Kebidanan Politeknik Kementerian Kesehatan Padang

Korespondensi: Husna Yetti, Email: husnayetti@med.unand.ac.id 


\section{PENDAHULUAN}

Menurut laporan World Health Organization (WHO) pada tahun 2013, Delapan dari Sepuluh negara dengan angka kematian ibu tertinggi yang tercatat baru-baru ini menghadapi bencana. Data Perserikatan Bangsa-Bangsa (PBB) dan United Nations Population Fund (UNFPA) melaporkan pada tahun 2015 bahwa sekitar 61\% dari kematian ibu terjadi di negara rawan bencana. Lebih dari sepertiga dari kasus kematian ibu terjadi ditengah bencana, salah satu penyebabnya adalah kurangnya peralatan dan personel yang berkualifikasi dalam sistim perawatan kesehatan. ${ }^{1}$

Wilayah barat Indonesia secara tektonik merupakan wilayah yang sangat dinamis. Hal ini disebabkan oleh proses subduksi/interaksi 2 lempeng, yaitu lempeng Indo-Australia dan Eurasia. Dengan adanya proses tersebut, provinsi Sumatera Barat merupakan salah satu yang rawan terhadap peristiwa gempa bumi. Potensi sumber gempa di provinsi Sumatera Barat terdapat pada 3 zona, yaitu pada zona Subduksi (baik inter dan intraplate), pada zona sesar Mentawai dan pada zona sesar Sumatera. ${ }^{2}$

Upaya memberikan pelayanan kesehatan pada kondisi krisis akibat bencana terus ditingkatkan namun belum optimal, baik dari tenaga kesehatan yang terlatih, peralatan, kompetensi maupun pengetahuan tenaga kesehatan tersebut dalam hal ini salah satunya tenaga bidan. Akibatnya pelayanan masih terbatas pada penanganan masalah kesehatan secara umum, sedang kesehatan reproduksi belum menjadi prioritas dan sering kali tidak tersedia. ${ }^{3}$

Bidan merupakan tenaga kesehatan yang pada umumnya bekerja di puskesmas atau yang berada di masyarakat/komunitas yang paling dekat terkena dampak dari bencana. Kontribusi bidan terhadap bencana/pengurangan risiko darurat atau kesiapsiagaan sangat penting. Bidan sering tidak termasuk dalam tenaga kesiapsiagaan bencana di tingkat lokal, nasional dan internasional. Hal ini didukung oleh fakta yang dari WHO yang menyebutkan bahwa kesehatan ibu, bayi baru lahir dan perempuan perlu diperhatikan dalam manajemen korban masal sehingga International Confrederation of Midwives (ICM) dan asosiasi anggotanya untuk memastikan bahwa bidan dapat berpartisipasi dan mengambil peran dalam kesiapsiagaan bencana. ${ }^{4}$

Bencana menimbulkan berbagai potensi permasalahan kesehatan bagi masyarakat. Dampak ini akan dirasakan lebih parah oleh kelompok penduduk rentan. Dalam Pasal 55 (2) UU Nomor 24 Tahun 2007 tentang Penanggulangan Bencana, kelompok rentan meliputi: I). Bayi, balita dan anakanak; 2). Ibu yang sedang mengandung atau menyusui; 3). Penyandang cacat; dan 4) Orang lanjut usia. ${ }^{5}$ Upaya perlindungan seharusnya diprioritaskan pada kelompok rentan tersebut, mulai dari penyelamatan, evakuasi, pengamanan sampai dengan pelayanan kesehatan dan psikososial. ${ }^{6}$

Puskemas kota Padang berjumlah 23 puskesmas, enam diantaranya berada di zona merah atau rawan bencana tsunami yaitu Puskesmas Lubuk Buaya, Puskesmas Air Tawar, Puskesmas Ulak Karang, Puskesmas Padang Pasir, Puskemas Seberang Padang dan Puskesmas Pemancungan. Studi pendahuluan yang peneliti lakukan terhadap 5 bidan yang bekerja di puskesmas yang akan dijadikan lokasi penelitian, didapatkan bahwa bidan lebih mendahului kesiapan diri sendiri/keluarga dan masih kurangnya pelatihan bagi bidan terkait dengan pelatihan managemen bencana. Hal tersebut berhubungan dengan faktor-faktor yang ada pada bidan yang bekerja di puskesmas yang nantinya dapat berpengaruh pada peran bidan dalam kesiapsiagaan bencana.

\section{METODE}

Penelitian ini menggunakan desain cross sectional yang dilakukan pada enam puskesmas rawan bencana kota Padang. Sampel dalam penelitian kuantitatif adalah 48 responden dengan teknik proporsional random sampling. Setelah didapatkan sampel di masing-masing Puskesmas, kemudian melakukan pengambilan sampel secara acak sederhana. Data dikumpulkan menggunakan kuesioner, Analisis dilakukan secara univariat dengan distribusi frekuensi, bivariat dengan uji Chi-square dan analisis multivariat dengan analisis logistik ganda. Kriteria inklusi dalam penelitian ini adalah Bidan dengan masa kerja $\geq 5$ tahun, bersedia menjadi 
responden, berada di terhpat pada saat penelitian (dua kunjungan). Kriteria ekslusi dalam penelitian ini adalah bidan yang sedang izin belajar dan sedang cuti.

Penelitian ini telah dilaksanakan di Puskesmas Lubuk Buaya, Puskesmas Air Tawar, Puskesmas Ulak Karang, Puskesmas Padang Pasir, Puskemas Seberang Padang dan Puskesmas Pemancungan pada bulan Oktober sampai November tahun 2018.

Instrumen Penelitian yang digunakan adalah kuesioner untuk variabel Tingkat Pengetahuan, Sikap, Pelatihan. Kuesioner yang digunakan dalam penelitian ini telah diuji validitasnya.

Prosedur penelitian adalah setiap bidan di Enam Puskesmas kota Padang berdasarkan pada perhitungan sampel dan sesuai dengan kriteria inklusi diberikan penjelasan tentang penelitian yang akan dilakukan. Untuk responden yang setuju, mereka akan diminta untuk menandatangani formulir persetujuan. Setelah itu, peneliti akan melakukan wawancara menggunakan kuesioner.

Pengumpulan data primer dilakukan dengan wawancara menggunakan kuesioner kepada bidan di enam puskesmas kota Padang sesuai dengan kriteria inklusi. Penelitian ini dilakukan setelah mendapatkan kelayakan etik (ethical clearence) dari Komite Etika Penelitian Fakultas Kedokteran Universitas Andalas Padang.

\section{HASIL}

Data penelitian diperoleh dengan mewawancarai 48 bidan yang dipilih di 6 (enam) Puskesmas kota Padang. Setelah data dianalisis secara univariat, bivariat dan multivariat kemudian diperoleh hasil sebagai berikut :

Tabel 1. Distribusi frekuensi kesiapsiagaan bidan dalam menghadapi bencana gempa dan tsunami di puskesmas kota Padang

\begin{tabular}{lcc}
\hline Kesiapsiagaan bidan & $\mathbf{f}$ & $\%$ \\
\hline Kurang siap & 25 & 52,1 \\
Siap & 23 & 47,9 \\
\hline Total & 48 & 100 \\
\hline
\end{tabular}

Berdasarkan Tabel 1 tampak 23 (47,9\%) responden siap dalam menghadapi bencana Gempa dan Tsunami di puskesmas kota Padang.
Tabel 2. Distribusi frekuensi faktor-faktor kesiapsiagaan bidan dalam menghadapi bencana Gempa dan Tsunami di puskesmas kota Padang

\begin{tabular}{lcc}
\hline \multicolumn{1}{c}{ Variabel } & f & $\%$ \\
\hline $\begin{array}{l}\text { Tingkat Pengetahuan } \\
\text { Rendah }\end{array}$ & \\
Tinggi & 23 & 49,9 \\
Sikap & 25 & 52,1 \\
$\quad$ Negatif & 20 & \\
$\quad$ Positif & 28 & 51,7 \\
Pelatihan & & \\
Tidak pernah & & \\
Pernah & 26 & 54,3 \\
\hline
\end{tabular}

Berdasarkan Tabel 2 dilihat bahwa sebagian besar responden memiliki tingkat pengetahuan tinggi, sebagian besar responden memiliki sikap positif, sebagian besar responden tidak pernah mengikuti pelatihan terkait kesiapsiagaan bencana.

Tabel 3. Hubungan tingkat pengetahuan, sikap, dan pelatihan dengan kesiapsiagaan bidan dalam menghadapi bencana Gempa dan Tsunami

\begin{tabular}{|c|c|c|c|c|c|c|c|}
\hline \multirow[t]{3}{*}{ Variabel } & \multicolumn{7}{|c|}{ Kesiapsiagaan Bidan } \\
\hline & \multicolumn{2}{|c|}{$\begin{array}{c}\text { Kurang } \\
\text { siap }\end{array}$} & \multicolumn{2}{|c|}{ Siap } & \multicolumn{2}{|c|}{ Jumlah } & \multirow[t]{2}{*}{$p$} \\
\hline & $f$ & $\%$ & $f$ & $\%$ & $\mathbf{f}$ & $\%$ & \\
\hline \multicolumn{8}{|l|}{$\begin{array}{l}\text { Tingkat } \\
\text { pengetahuan }\end{array}$} \\
\hline - Tinggi & 18 & 78,3 & 5 & 21,7 & 23 & 100 & 0,001 \\
\hline - Rendah & 7 & 28,0 & 18 & 72,0 & 25 & 100 & \\
\hline \multicolumn{8}{|l|}{ Sikap } \\
\hline - Negatif & 15 & 75,0 & 5 & 25,0 & 20 & 100 & 0,017 \\
\hline - Positif & 10 & 35,7 & 8 & 64,3 & 28 & 100 & \\
\hline \multicolumn{8}{|l|}{ Pelatihan } \\
\hline 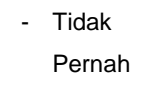 & 19 & 73,1 & 7 & 26,9 & 26 & 100 & 0,004 \\
\hline - Pernah & 6 & 27,3 & 16 & 72,7 & 22 & 100 & \\
\hline
\end{tabular}

Berdasarkan Tabel 3 dapat dilihat bahwa ada hubungan yang signifikan antara tingkat pengetahuan, sikap, pelatihan dengan kesiapsiagaan bidan dalam menghadapi bencana Gempa dan Tsunami di puskesmas kota Padang, dimana didapatkan pada semua variabel dengan $p<0,05$. 
Tabel 4. Analisis regresi logistik sederhana

\begin{tabular}{lcc}
\hline Variabel & $\mathbf{p}$ & $\begin{array}{c}\text { Masuk } \\
\text { model }\end{array}$ \\
\hline Tingkat pengetahuan & 0,001 & + \\
Sikap & 0,017 & + \\
Pelatihan & 0,004 & + \\
& & \\
\hline
\end{tabular}

Berdasarkan Tabel 4 diatas menunjukkan
analisis bivariat didapatkan semua variabel
mempunayi nilai $p<0,25$.

Tabel 5. Analisis faktor yang paling dominan yang berhubungan dengan kesiapsiagaan bidan dalam menghadapi bencana Gempa dan Tsunami.

\begin{tabular}{lrrrrr}
\hline Variabel & B & SE & Wald & Sig & Ekp $\boldsymbol{\beta}$ \\
\hline Step 1 & & & & & \\
Tingkat & .888 & .879 & 1.019 & .313 & 2.429 \\
pengetahuan & & & & & \\
Sikap & .945 & .770 & 1.505 & .220 & 2.573 \\
Pelatihan & 1.891 & .890 & 4.512 & .034 & 6.629 \\
Step 2 & & & & & \\
Sikap & 1.043 & .757 & 1.897 & .168 & 2.838 \\
Pelatihan & 2.405 & .749 & 10.318 & .001 & 11.075 \\
\hline
\end{tabular}

Berdasarkan Tabel 5 dapat dilihat bahwa pelatiha merupakan faktor dominan terhadap kesiapsiagaan bidan dalam menghadapi bencana Gempa dan Tsunami dengan nilai $p<0,005$. Untuk melihat variabel mana yang paling besar pengaruhnya terhadap variabel independen, dilihat nilai exp (B), artinya semakin besar nilai $\exp (B)$ berarti semakin besar pengaruhnya terhadap variabel dependen. Nilai eksponen beta (exp B) paling besar pada variabel pelatihan yaitu 11,075 artinya jika sistim peringatan bencana baik maka kesiapsiagaan bidan dalam menghadapi bencana berpeluang 11 kali lebih baik.

\section{PEMBAHASAN}

\section{Kesiapsiagaan Bidan}

Sebagian besar $(56,5 \%)$ responden kurang siap dalam menghadapi bencana Gempa dan Tsunami di puskesmas kota Padang. Hasil penelitian ini hampir sama dengan penelitian Maslida Intan (2016) responden dalam kategori tidak siap yaitu $71,05 \%$ dalam menghadapi bencana Gempa dan Tsunami. $^{7}$ Hasil penelitian ini juga didukung oleh studi Ristrini et al (2011) bahwa kesiapsiagaan merupakan tahapan yang penting dalam penanggulangan bencana yang harus diantisipasi oleh unsur pemerintah, swasta maupun masyarakat, kesiapsiagaan tersebut bisa dalam bentuk pengembangan peraturan, penyiapan program, pendanaan dan pengembangan jejaring lembaga atau organisasi siaga bencana. ${ }^{8}$

Perawat dan bidan dapat memainkan peran penting dalam pengurangan risiko darurat, kesiapsiagaan dan tanggapan. Perawat dan bidan merupakan kelompok terbesar tenaga kesehatan di sebagian besar negara dan sudah terpapar dengan perawatan klinis, manajemen dan komunikasi. Perawat dan bidan bekerja erat dengan kelompok kurang beruntung dan rentan yang paling sering terkena dampak terjadinya keadaan darurat dan bencana. Mereka mungkin dikenal dan dipercaya di komunitas mereka. Namun, perawat dan bidan sering tidak diikutsertakan dalam keadaan darurat, persiapan dan perencanaan respons. Ketika bencana terjadi, orang yang rentan mungkin dibiarkan tanpa akses yang efektif ke perawatan. Hal ini akan berdampak pada tanggapan layanan karena kekurangan staf yang berkualifikasi sehingga meminta bantuan dari luar. ${ }^{4}$

\section{Tingkat Pengetahuan}

Sebagian besar $(52,1 \%)$ responden memiliki tingkat pengetahuan tinggi tentang kesiapsiagaan menghadapi bencana Gempa dan Tsunami di puskesmas kota Padang tahun 2018. Penelitian ini hampir sama dengan penelitian Husna C (2013) yaitu $63,3 \%$ responden memperoleh tingkat pengetahuan tinggi tentang kesiapsiagaan bencana. ${ }^{9}$ Hasil ini juga hampir sama dengan Devi Ashalata (2015) yaitu pengetahuan maksimal 58\% responden memiliki pengetahuan yang cukup tentang kesiapan gempa. ${ }^{10}$ Berbeda dengan hasil penelitian Taghizadehet al (2017) hanya $33,7 \%$ memiliki tingkat pengetahuan tentang kesiapsiagaan menghadapi bencana. ${ }^{11}$

Hasil ini relevan dengan penelitian Rifai dan Harnanto (2016) didapatkan bahwa mayoritas perawat dan bidan memiliki pengetahuan yang baik dalam hal kesiapsiagaan bencana. Kontribusi perawat dan bidan didapatkan beberapa komponen yang dirasakan masih kurang yaitu tentang pembentukan gugus dan tim siaga bencana. Pendidikan dan pelatihan 
terehadap para perawat dan bidan untuk meningkatkan kapasitas dalam manajemen kesiagaan bencana. $^{12}$

Notoatmodjo (2012) menjelaskan bahwa pengetahuan merupakan hasil tahu dan hal ini terjadi setelah seseorang melakukan penginderaan terhadap suatu objek tertentu. Penginderaan terjadi melalui panca indera manusia, yaitu indera penglihatan, pendengaran, penciuman, rasa dan raba. Sebagian besar pengetahuan manusia diperoleh melalui mata dan telinga. Pengetahuan atau kognitif merupakan domain yang sangat penting untuk terbentuknya tindakan seseorang (overt behavior). ${ }^{13}$

Pengetahuan yang baik akan mempengaruhi seseorang melakukan tindakan, pengetahuan dapat diperoleh dari hal yang bersifat formal misalnya pendidikan, seminar, pelatihan sedangkan non formal dapat diperoleh seseorang dari orang lain, media cetak maupun elektonik. Di era modern ini semua orang dapat mengakses informasi atau pengetahuan dengan sangat mudah melalui internet. Hasil penelitian ini masih ditemukan responden dengan pengetahuan yang rendah tentang kesiapsiagaan bencana terutama berkaitan dengan perencanaan kesehatan reproduksi komprehensif pasca bencana dan alat yang harus dipersiapkan tenaga kesehatan baik pada tahap prabencana, tanggap darurat maupun pasca bencana.

\section{Sikap}

Sebagian besar responden (58,3\%) memiliki sikap positif dalam menghadapi bencana Gempa dan Tsunami di puskesmas kota Padang tahun 2018. Hasil penelitian ini relevan dengan hasil penelitian Maslida Intan (2016) yaitu sikap perawat terhadap kesiapsiagaan bencana Gempa dan Tsunami diperoleh hasil $100 \%$ kategori baik. ${ }^{7}$ Hasil penelitian ini juga didukung oleh Adeneken et al (2012) yaitu sikap responden terhadap kesiapsiagaan darurat pada umumnya positif $(93,2 \%)$, karena kebanyakan dari mereka percaya bahwa mereka perlu tahu tentang perencanaan darurat. Manajemen sadar akan kesiapsiagaan bencana dan memiliki sikap terhadap rencana kesiapsiagaan yang positif. ${ }^{14}$
Sikap merupakan respon atau reaksi tertutup dari seseorang yang ditunjukan dengan adanya kesesuaian terhadap suatu stimulus atau objek yang dalam kehidupan sehari-hari, dimana reaksinya bersifat emosional terhadap stimulus sosial. Sikap belum merupakan suatu tindakan, tetapi merupakan predisposisisi tindakan suatu perilaku, jadi sikap merupakan kesiapan untuk bertindak terhadap objek di lingkungan tertentu sebagai suatu penghayatan terhadap objek. ${ }^{15}$

Banyak respoden yang memiliki sikap positif tentang kesiapsiagaan menghadapi bencana dikarenakan rasa tanggung jawab dan kepedulian yang sangat tinggi terhadap pasien ataupun masyarakat yang terkena bencana. Hal ini dapat dilihat dari jawaban responden melalui kuesioner dimana responden bersedia terlibat dan menjadi tim jika terjadi bencana dan bersedia bekerja di luar jam rutin. Meskipun tingkat pengetahuan yang didapatkan masih banyak yang rendah sedangkan sikap mereka merespon dengan baik hal ini dikarenakan mereka juga menyadari akan profesi mereka sebagai pemberi pelayanan kesehatan baik didalam kondisi normal maupun saat terjadi bencana.

\section{Pelatihan}

Sebagian besar (54,2\%) responden tidak pernah mengikuti pelatihan tentang kesiapsiagaan menghadapi bencana Gempa dan Tsunami di puskesmas kota Padang tahun 2018. Penelitian ini hampir sama dengan Dewi Ruky Nurul Wursanti tahun 2010 yaitu 44,6 \% responden pernah mengikuti pelatihan tentang kesiapsiagaan bencana. ${ }^{16}$

Bidan merupakan salah satu tenaga kesehatan yang termasuk dalam tim bantuan kesehatan. Oleh karena itu diperlukan kesiapsiagaan bidan dalam menangani krisis kesehatan sebagaimana dijelaskan dalam Keputusan Menteri Kesehatan RI. No.066/MENKES/SK/II/2006 tentang pedoman sumber daya manusia kesehatan dalam penanggulangan bencana. ${ }^{17}$

Pelatihan atau kompetensi minimal yang diikuti bidan untuk kesiapsiagaan bencana antara lain Asuhan Persalinan Normal (APN), Pelayanan Obstetri 
Neonatal Emergency Dasar (PONED). ${ }^{17}$ Pelatihan lain yang diperlukan antara lain yaitu PPAM kesehatan reproduksi krisis kesehatan, Basic Training Cardiac Live Support (BTCLS), Pertolongan pertama kegawatdaruratan obstetrik dan neonatus (PPGDON), Pencegahan infeksi, pelatihan manajemen bencana dan pelatihan penunjang lainnya. ${ }^{3}$

\section{Hubungan tingkat pengetahuan dengan kesiapsiagaan menghadapi bencana Gempa dan Tsunami}

Terdapat hubungan yang bermakna antara tingkat pengetahuan dengan kesiapsiagaan bidan dalam menghadapi bencana gempa dan tsunami di puskesmas kota Padang dimana didapatkan $p$ value $<0,05$ yaitu 0,001 . Hasil penelitian ini sama dengan penelitian Bukhari et al (2013) tentang kesiapsiagaan bencana gempa bumi di BLUD rumah sakit lbu dan anak Pemerintah Aceh, didapatkan terdapat hubungan antara pengetahuan dengan kesiapsiagaan bencana gempa bumi dengan p-value 0,004. Hasil penelitian ini ditemukan bahwa upaya kesiapsiagaan terhadap bencana gempa dan tsunami yang baik sangat didukung oleh pengetahuan yang cukup tentang teknik dan prosedur dari perencanaan, mitigasi dan tindakan evakuasi saat bencana serta harus didukung kesadaran dan tanggung jawab terhadap upaya kesiapsiagaan tersebut. ${ }^{18}$

Penelitian diatas sejalan dengan penelitian Lalonde dan Adrien (2015), dimana bantuan bencana telah menjadi fokus utama pemerintah negara bagian dan lokal, namun tim bencana dan tenaga bantuan seringkali kekurangan keahlian khusus atau pelatihan dalam perawatan perempuan. Kurangnya pengetahuan terhadap wanita hamil diperencanaan bencana menyebabkan kurangnya kesiapan dalam perawatan essensial dan memberikan kesempatan untuk peningkatan promosi dalam perencanaan bantuan bencana oleh lembaga pemerintah. ${ }^{19}$

Pengetahuan yang dimiliki seseorang biasanya dapat mempengaruhi sikap dan kepedulian untuk siap siaga dalam mengantisipasi bencana terutama bagi masyarakat yang tinggal di daerah potensi bencana. Untuk meningkatkan bencana maka jajaran kesehatan dalam hal ini bidan harus memiliki sikap dan kepedulian terhadap resiko bencana. ${ }^{20}$
Pengetahuan dan keterampilan profesional perawat kesehatan dan persepsi tentang pentingnya layanan perawatan kesehatan di daerah bencana diperlukan untuk meningkatkan kesiapsiagaan dalam menghadapi bencana. Selain pentingnya pengetahuan dan keterampilan hal lain yang diperlukan adalah kesadaran akan tugas dalam pelayanan kesehatan menghadapi bencana. ${ }^{11}$

Suatu kegiatan mitigasi bencana sangat diharapkan oleh setiap lapisan masyarakat termasuk profesi bidan, sehiggga tidak ada lagi yang tidak mengetahui bencana dan kesiapsiagaan menghadapi bencana tersebut misalnya gempa dan tsunami serta resiko yang ditimbulkannya. Jika hal tersebut terjadi maka semua lapisan masyarakat tidak lagi khawatir yang berlebihan karena sudah siap sedia dengan pengetahuan yang mereka dapatkan dari berbagai pihak atau pemerintah. Secara professional bidan diharapkan harus mempunyai pengetahuan yang baik terhadap kesiapsiagaan, untuk tercapainya kesiapsiagaan yang baik maka bidan harus memiliki pengetahuan dan kompetensi sesuai dengan wewenangnya yang diperoleh dari pendidikan formal dan non formal maupun pelatihan tentang kesiapsiagaan bencana.

\section{Hubungan sikap bidan dengan kesiapsiagaan dalam menghadapi bencana gempa dan tsunami}

Terdapat hubungan yang bermakna antara sikap dengan kesiapsiagaan bidan dalam menghadapi bencana gempa dan tsunami di puskesmas kota Padang dengan $\mathrm{p}<0,05(0,017)$. Hasil penelitian ini didukung oleh Bukhari et al (2013) tentang kesiapsiagaan bencana gempa bumi di BLUD rumah sakit lbu dan Anak Pemerintah Aceh, didapatkan terdapat hubungan antara sikap dengan kesiapsiagaan bencana gempa bumi yaitu $p=0,003$ berarti terdapat hubungan yang bermakna antara sikap dengan kesiapsiagaan bencana gempa bumi oleh perawat pelaksana. ${ }^{18}$

Menurut Aldina et al (2014) sikap sangat berperan dalam kesiapsiagaaan seseorang dalam menyelamatkan diri dari bencana artinya semakin baik sikap tentang bencana, maka akan semakin siap dalam menghadapi bencana, khususnya gempa dan tsunami. ${ }^{21} \mathrm{Hal}$ ini didukung oleh LIPI/UNESCO/ISDR 
(2006) dimana sikap dan rasa peduli dapat dipengaruhi oleh pengetahuan yang dimiliki untuk siap siaga dalam mengantisipasi bencana terutama bagi masyarakat yang tinggal didaerah potensi bencana. Dalam meningkatkan kesiapsiagaan bencana maka tenaga kesehatan dan jajarannya dalam hal ini bidan harus memiliki sikap dan kepedulian yang baik terhadap resiko bencana. ${ }^{20}$

Sikap yang peduli menjadikan semangat untuk kesiapsiagaan baik untuk diri sendiri maupun pasien sehingga pada proses penyelamatan diri dapat terjadi. Sikap akan mempengaruhi perilaku seseorang melalui suatu proses pengambilan keputusan dalam hal ini sikap bidan dalam mengambil keputusan untuk tetap melakukan kesiapsiagaan dari bencana gempa dan tsunami. Semakin baik sikap yang dimiliki bidan maka semakin siap bidan dalam menghadapi jika terjadi bencana Gempa dan Tsunami.

\section{Hubungan pelatihan dengan kesiapsiagaan menghadapi bencana gempa dan tsunami}

Terdapat hubungan yang bermakna antara pelatihan dan kesiapsiagaan dalam menghadapi bencana gempa dan tsunami di puskesmas kota Padang dengan $p<0,05$ yaitu 0,004 . Hasil penelitian ini sama dengan penelitian Dewi Ruky Nurul Wursanti (2010) tentang kesiapsiagaan sumber daya kesehatan menghadapi bencana didapatkan terdapat hubungan antara pelatihan dengan kesiapsiagaan bencana dengan nilai $p=0,002 .^{16}$

Pelayanan kesehatan reproduksi saat bencana sangat penting. Persiapan anggota atau tim kesehatan kesiapsiagaan bencana untuk penyedia layanan perawatan reproduksi saat ini masih sangat terbatas, oleh karena itu peningkatan kompetensi professional perawatan kesehatan sangat diperlukan. Bidan sebagai salah satu anggota tim bencana bertanggungjawab untuk menyediakan tanggapan yang tepat untuk kebutuhan perawatan kesehatan wanita, bayi baru lahir dan bayi serta anak-anak. Respon cepat dan manajemen yang tepat dalam keadaan darurat obstetric dapat menyelamatkan kehidupan ibu dan kelompok rentan lainnya. ${ }^{1}$

Pelatihan sangat diperlukan dalam hal meningkatkan kesiapsiagaan bencana, sebagaimana yang dijelaskan dalam Buku Pedoman Paket Awal
Minimum (PPAM) kesehatan reproduksi krisis kesehatan tahun 2015. Terdapat tiga tahapan bencana yaitu pra bencana, tanggap darurat bencana dan pasca bencana. dimana bidan di harapkan mengikuti pelatihan terkait managemen bencana, pelatihan penujang teknis lainnya berkaitan dengan kompetensi yang dimiliki pada tahap prabencana, sehingga jika terjadi bencana bidan mampu melakukan pertolongan pada korban khususnya kelompok rentan pada tahap pasca bencana. ${ }^{3}$

\section{SIMPULAN}

terdapat hubungan antara tingkat pengetahuan, sikap dan pelatihan terhadap kesiapsiagaan bidan dalam menghadapi bencana gempa dan Tsunami di puskesmas kota Padang.

\section{UCAPAN TERIMA KASIH}

Terima kasih kepada semua pihak yang telah memberikan kontribusi dalam penelitian ini.

\section{DAFTAR PUSTAKA}

1. World Health Organization (WHO). Maternal mortality. 2013 (diunduh 4 Oktober 2018). Tersedia dari: http://www.who.int/mediacentre/factsheets/ fs348/en/index.html.

2. Badan Penanggulangan Bencana Daerah (BPBD). Kajian risiko bencana kota Padang Sumatera Barat Tahun 2014 - 2018. Padang: BPBD; 2013.

3. Kementerian Kesehatan RI. Buku pedoman paket pelayanan awal minimum (PPAM), kesehatan reproduksi pada krisis kesehatan. Jakarta: Kementerian Kesehatan RI: 2015.

4. World Health Organization (WHO). Regional case study on role of nurses and midwives in emergencies and disasters. WHO; 2011.

5. UU Nomor 24 tentang Penanggulangan Bencana. tahun 2007

6. Badan Nasional Penanggulangan Bencana (BNPB). Peraturan kepala badan nasional penanggulangan bencana tentang pedoman penyusunan rencana penanggulangan bencana. Jakarta: BNPB; 2008.

7. Maslida I. Faktor-faktor yang berhubungan dengan tingkat kesiapsiagaan perawat pada puskesmas 
yang berisiko bencana tsunami di Banda Aceh. [tesis]. Banda Aceh: Universitas Syiah Kuala; 2016.

8. Ristrini, Rukmini, Oktarina. Analisis implementasi kebijakan kesiapsiagaan penanggu langan bencana bidang kesehatan di provinsi Sumatera Barat. Buletin Penelitian Sistem Kesehatan. 2011;15(1):91-102.

9. Husna C. Faktor-faktor yang Mempengaruhi Kesiapsiagaan Bencana Di RSUD ZA Banda Aceh. Idea Nursing Jurnal. 2011;3(2):10-9.

10. Devi A, Sharma D. Awareness on earthquake preparedness $A$ key to safe life. International Journal of Nursing Research and Practice. 2015;2(2):1-6.

11. Taghizadeh A, Khoshnam, RM, Kazemnejad A. Midwives' professional competency for preventing neonatal mortality in disasters. Health in Emergencies and Disasters Quarterly. 2017; 1 (3): 155-62.

12. Rifai A, Harnanto AM. Analisis kapasitas fungsional perawat dan bidan RSUD kota Surakarta dalam pengembangan program hospital preparedness for emergency and disaster. Jurnal Terpadu Ilmu Kesehatan. 2016;5(1):69-74.

13. Notoatmodjo S. Promosi Kesehatan dan perilaku kesehatan. Jakarta: Rineka Cipta; 2012.hlm.131-4.

14. Adenekan, Mobolanle R, Balogun, Victor I. Knowledge, attitude, and practices of emergency health workers toward emergency preparedness and management in two hospitals in Lagos. Journal of Clinical Sciences.2016;13(1):23-7.
15. Effendi F, Makhfudli. Keperawatan kesehatan komunitas teori dan praktek dalam keperawatan. Jakarta: Salemba medika; 2009.hIm.68-9.

16. Wursanti DRN. Kesiapsiagaan sumber daya manusia kesehatan dalam penanggulangan masalah kesehatan akibat bencana banjir di provinsi DKI [tesis]. Depok: Universitas Indonesia; 2010.

17. Keputusan Menteri Kesehatan RI. No.066/MENKES/SK/II/2006 tentang pedoman sumber daya manusia kesehatan dalam penanggulangan bencana. Kemenkes RI.

18. Bukhari, Mudatsir, Sari SA. Hubungan sikap tentang regulasi pengetahuan dan sikap perawat terhadap kesiapsiagaan bencana gempa bumi di badan layanan umum daerah rumah sakit ibu dan anak pemerintah Aceh. Jurnal IImu Kebencanaan (JIKA) Pasca Sarjana Universitas Syiah Kuala. 2013;2(1):37-46.

19. Lalonde A, Adrien L. The role of obstetrics and gynecology national societies during natural disasters. International Journal of Gynecology \& Obstetrics. 2015;(13)1:89-92.

20. LIPI/UNESCO/ISDR. Pengembangan framework kajian kesiapsiagaan masyarakat dalam mengantisipasi bencana. 2006 (diunduh $20 \mathrm{Mei}$ 2018. Tersedia dari: http://www.coremap.or.id/i/.pdf 21. Aldina, Agussabti, Hermansyah. Kesiapsiagaan Masyarakat dalam Menghadapi Situasi Bencana Gunung Api Seulawah Agam di Wilayah Kecamatan Sare Kabupaten Aceh Besar. Jurnal IImu Kebencanaan (JIKA) Pasca Sarjana Universitas Syiah Kuala. 2014;1(1):20-2. 